\section{International Scientific Journal Theoretical \& Applied Science}

\author{
p-ISSN: 2308-4944 (print) e-ISSN: 2409-0085 (online) \\ Year: 2015 Issue: 10 Volume: 30 \\ Published: $30.10 .2015 \quad$ http://T-Science.org
}

Inna Aleksandrovna Serebryanik

Candidate of Technical Sciences, associate professor of the Department of World economy, Irkutsk National Research Technical University, Russia nasamolet@yandex.ru

SECTION 31. Economic research, finance, innovation, risk management.

\title{
UNITED ARAB EMIRATES: ECONOMIC GUIDE
}

Abstract: The article considers the features of economic development United Arab Emirate. Analyzes the role of fuel and energy complex. The estimation of investment attractiveness of the country.

Key words: Arab Emirates, UAE, oil, diversification, investment.

Language: Russian

Citation: Serebryanik IA (2015) UNITED ARAB EMIRATES: ECONOMIC GUIDE. ISJ Theoretical \& Applied Science 10 (30): 24-27.

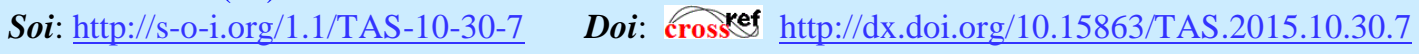

\section{ОБЪЕДИНЕННЫЕ АРАБСКИЕ ЭМИРАТЫ: ЭКОНОМИЧЕСКИЙ ПУТЕВОДИТЕЛЬ}

Аннотация: В статье рассмотрены особенности экономического развития Объединенных Арабских Эмират. Проанализирована роль топливно-энергетического комплекса. Дана оценка инвестиционной привлекательности страны.

Ключевые слова: Арабские Эмираты, ОАЭ, нефть, диверсификацุия, инвестиции.

Объединенные Арабские Эмираты (ОАЭ) удивительная страна, в которой сочетаются новейшие технологии и удивительная традиционность. Традиционность объяснима, в том числе и тем, что арабы являются одним из старейших народов мира.

ОАЭ - это маленькая страна, в которой живет 9,3 миллионов жителей. $85 \%$ ее территории занимает пустыня. При этом ОАЭ очень богатая и влиятельная конфедерация семи княжеств.

До 1950-х гг. ОАЭ были ничем не примечательной экономикой, которая базировалась на рыболовстве и ловле жемчуга. Ловля жемчуга начиналась с приходом лета. Жители из оазисов устремлялись на морское побережье. За двухминутное ныряние опытный ныряльщик может достать до 10 раковин [4]. Сегодня жемчуг выращивают на плантациях, доля ОАЭ на мировом рынке - около 50\%. Одним из тех, кто помог ОАЭ получить данные о том, что страна богата нефтью был Ж.Кусто, который в 1952 году брал пробы подводного грунта на территории страны. С1962 г. Абу-Даби стал экспортировать нефть.

2 декабря 1971 г. шесть эмиратов: Абу-Даби, Дубай, Шарджа, Аджман, Фуджейра Ум-аль-
Кувейн объединились в государство Объединенные Арабские Эмираты. 10 февраля 1972 г. к ним присоединился эмират Рас-альХайма. Только два эмирата можно назвать крупными - Абу-Даби и Дубай. Это хорошо видно на карте (рисунок 1).

В 1973 году цены на нефть выросли. Прошло порядка 25 лет, и ОАЭ получили высокоразвитую экономику. Если раньше шейхи жили в шатрах, то потом их сменили роскошные резиденции.

По запасам нефти ОАЭ занимает шестое место в мире. При этом в четырех из семи эмиратах нефти нет. Основные запасы сконцентрированы в двух эмиратах - Абу-Даби $(85 \%)$, Дубай (15\%). ОАЭ по запасам газа занимает четвертое место в мире, после России, Ирана и Катара.

Конечно, ТЭК играет доминирующую роль в экономике страны. Нефтегазовый сектор дает $1 / 3$ ВВП и 75-80\% дохода бюджета, а также большую часть экспортных доходов. При этом в структуре ВВП 44\% представлено сектором услуг (56\% производство, 1\% - сельское хозяйство) [2]. 


\begin{tabular}{|c|c|c|c|c|c|c|}
\hline Impact Factor: & $\begin{array}{l}\text { ISRA (India) } \\
\text { ISI (Dubai, UAE } \\
\text { GIF (Australia) } \\
\text { JIF }\end{array}$ & $\begin{array}{l}=1.344 \\
=0.829 \\
=0.356 \\
=1.500\end{array}$ & $\begin{array}{l}\text { SIS (USA) } \\
\text { PИНЦ (Russia) } \\
\text { ESJI (KZ) } \\
\text { SJIF (Morocco) }\end{array}$ & $\begin{array}{l}=0.912 \\
=0.179 \\
=1.042 \\
=2.031\end{array}$ & ICV (Poland) & $=6.630$ \\
\hline
\end{tabular}

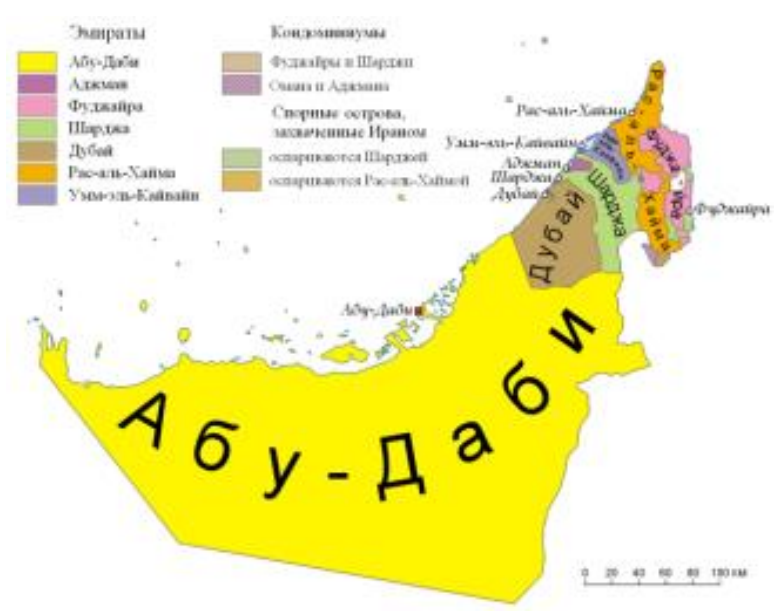

Рисунок 1 - Объединенный Арабские Эмираты.

Из всех стран Персидского залива экономика ОАЭ наименее зависима от цены на нефть, ибо может считаться хорошо диверсифицированной. В стране развиты химическая, алюминиевая, цементная, судоремонтная отрасли промышленности.

Государство делает высокие вложения в сельское хозяйство, так как оно только на четверть обеспечивает внутренние потребности страны. И это при том, что только $0,77 \%$ территории пригодны для ведения сельского хозяйства. Большая часть инвестиций идет в строительство опреснительных заводов.

В стране хорошо развито скотоводство (бараны и козы, блюда из которых составляют основу рациона местных жителей). В ОАЭ выращивают верблюдов. Цена за одного верблюда может достигать 750 тыс. евро. Большая часть из них используется, как тягловые животные. Они единственные способны идти в песчаную бурю, зажимая ноздри, без капли воды до 4-х дней. Кроме того, он может пить соленую воду. Его копыта не вязнут в песке, и верблюд способен везти груз в 200 кг. Самка верблюда дает 25 литров молока в день, даже в условиях жары. Помет верблюда используется как топливо, ведь ночная температура в пустыне может опускаться до 0. Для того, чтобы выжить в пустыне достаточно 9 фиников и кружки молока в день. Так, по преданию, питался сам пророк Магомет.

Несмотря на то, что в эмиратах есть возможности ведения оффшорного бизнеса, иностранному капиталу интересен реальный бизнес. Свободные экономические зоны ОАЭ предоставляют такую возможность. Самые известные из них:

1. Dubai Intl. Financial Center - бизнес-парк, основной специализацией которого является полный спектр финансовых услуг;

2. ENPARK - зона для компаний, которые производят экологические продукты и технологии, связанные с защитой окружающей среды;

3. Dubai Cars\&Automotive Zone - зона для компаний автоиндустрии;

4. Dubai Airport Free Zone - хаб для авиационных, грузовых, логистических, фармацевтических и других компаний;

5. Fujairah Creative city - СЭ3 в сфере медиа, консалтинга, коммуникаций и т.д.;

6. Dubai International Academic City - зона, объединяюая образовательные заведения Дубаи.

Налог на прибыль и НДС в стране отсутствует, исключение составляет банковская деятельность и добыча нефти. Здесь также нет налога на доходы физических лиц. Иностранные граждане не имеют возможности купить землю, только аренда на 99 лет. Такие условия вполне приемлемы для иностранных компаний, работающих в ОАЭ.

Помимо этого компании, работающие в ОАЭ, получают доступ на широкий рынок таможенного пространства стран Персидского залива - Саудовская Аравия, Бахрейн, Катар, Оман, Кувейт. Транспортно-логистическая инфраструктура ОАЭ считает одной из лучших в мире. Особенно выделяется портовая инфраструктура, как на Индийском океане, так и в Персидском заливе.

Демократизм политического устройства ОАЭ заключается в том, что семь монархов избирают из своего числа пожизненного президента. Им является руководитель крупнейшего княжества - Абу-Даби - шейх Зайяд 
бен Султан аль-Нахайян, а правитель второго по значению княжества Дубаи шейх Мактум бен Рашед аль-Мактум - вице-президент и премьер. Дубайцам повезло с шейхами. Руководство страны давно разглядело две отдаленные угрозы. Первая - нефти на территории княжества не столь уж много. И они стали развивать те отрасли, которые могут обеспечить саморазвитие. В первую очередь индустрию отдыха. Побережье ОАЭ словно бы специально создано для отдыха. Здесь круглый год тепло и солнечно. Летом воду в бассейнах охлаждают, зимой - нагревают.

Многие правительственные чиновники также управляют бизнесом, равно как и члены королевских семей. Это воспринимается вполне нормально, не так как в Европе или в Северной Америке.

Огромные нефтяные доходы помогли создать в стране хорошую социальную систему. Любой житель страны может получить образование в любой стране мире за счет государства. В ОАЭ один из самых высоких уровней жизни среди стран Персидского залива и в мире. Третье место заняли резервные фонды Арабских Эмиратов (Abu Dhabi Investment Authorities) с активами $\$ 863$ млрд.

Пенсии в ОАЭ - это $60 \%$ от базовой заработной платы при наличии страхового стажа не менее 15 лет. Доступ к пенсии открыт по достижении 20 лет стажа и минимального пенсионного возраста (55 лет для мужчин и 50 лет для женщин). Государство поощряет граждан работать дольше, начисляя за каждый дополнительный год $2 \%$ и так вплоть до $100 \%$ от базовой заработной платы.

Медицинское обслуживание бесплатно для всех граждан ОАЭ. Государство на 90\% покрывает стоимость потребленной воды и электричества для жителей страны.

Страна отличается драконовским миграционным законодательством. Получить гражданство невозможно. Как только мигранту исполняется 60 лет, его без разговоров выпроваживают из страны. Так что врасти в почву, пустить корни, а потом создавать проблемы местному правительству у приезжих пока не получается. Рабочую визу очень легко потерять - достаточно как-нибудь провиниться на работе или в общественном месте. Кстати, общественный порядок в Дубаи идеальный.

Дешевую и черную работу в ОАЭ выполняют приезжие из Индии, Афганистана, Пакистана, Бангладеш. Разрешение на работу получают лишь те, у кого есть рекомендация от гражданина ОАЭ. Если мигрант лишится работы, то он должен будет за 30 дней выехать из страны. Приезжие работают в несколько смен, строители даже в ночную. Мигрантов в стране почти $30 \%$ от общего населения.
В отличие, например, от Саудовской Аравии, в ОАЭ либеральные взгляды. Женщина может учиться, водить машину, совершать покупки самостоятельно. Тем не менее, ОАЭ глубоко религиозная страна, в которой минареты важнее небоскребов.

ОАЭ - страна роскоши и блеска. Покупка золотых украшений в ОАЭ не облагается налогами. Примерно 10\% всего мирового спроса на них сосредоточено здесь.

ОАЭ постоянно улучшают свои позиции на международном рынке инвестиций. Ежегодное исследование Всемирного Банка «Ведение бизнеса» (оценка простоты ведения бизнеса) определяет ОАЭ 22 место из 189 стран (2015 год). В 2013 году страна занимала 26 место, а в 2014 25 [1].

Основными торговыми партнерами ОАЭ (2014 год) являются Китай (14,7\%), Индия (14\%), США $(10,8 \%)$, Великобритания (6\%) и Германия $(5,1 \%)$. Доля российского импорта в 2014 г. составляла $0,7 \%$. Продукция российских компаний также востребована на рынке ОАЭ, особенно это касается следующих товарных групп [3]:

1. Водоочистка и водопереработка;

2. Холодильное оборудование;

3. Продукты питания;

4. Энергосберегающее освещение;

5. Контрольно-измерительное оборудование;

6. Экотехнологии;

7. Информационные технологии;

8. Противопожарное оборудование;

9. И др.

ОАЭ поставляют в Россию следующие товары:

1. Реакторы ядерные, котлы, оборудование и механические устройства, их части;

2. Кофе, чай, мате, или парагвайский чай, и пряности;

3. Изделия из черных металлов;

4. Пластмассы и изделия из них;

5. Органические химические соединения;

6. И др.

Российский бизнес нашел свое место в ОАЭ. Например, в одной только Шардже, в свободной экономической зоне «Аэропорт Шарджи « зарегистрировано 200 российских компаний, в «Хамрии» - 140 и еще 125 фирм - на основной территории [9].

Основная проблема, с которой сталкиваются предприятия, работая в ОАЭ - это отсутствие практического опыта работы на зарубежных рынках, а также необъективная оценка своих возможностей.

Подводя итоги, следует отметить, что экономика Арабских Эмиратов - это экономика стабильности. Даже события «Арабской весны» 


\begin{tabular}{|c|c|c|c|c|c|c|}
\hline Impact Factor: & $\begin{array}{l}\text { ISRA (India) } \\
\text { ISI (Dubai, UAF } \\
\text { GIF (Australia) } \\
\text { JIF }\end{array}$ & $\begin{array}{l}=1.344 \\
=\mathbf{0 . 8 2 9} \\
=\mathbf{0 . 3 5 6} \\
=1.500\end{array}$ & $\begin{array}{l}\text { SIS (USA) } \\
\text { PИHЦ (Russia) } \\
\text { ESJI (KZ) } \\
\text { SJIF (Morocco) }\end{array}$ & $\begin{array}{l}=0.912 \\
=0.179 \\
=1.042 \\
=2.031\end{array}$ & ICV (Poland) & $=6.630$ \\
\hline
\end{tabular}

не поколебали ее. «Большие деньги любят тишину» - это как раз формула инвестиций в ОАЭ.

\section{References:}

1. (2015) Sajt gruppy Vsemirnogo banka. Doing business. Available: http://russian.doingbusiness.org/rankings (Accessed: 1.10.2015).

2. (2015) United Arab Emirates Doing Business 2015 Economy Profile- Available: http://russian.doingbusiness.org/data/exploreeco nomies/ /media/giawb/doing\%20business/docu ments/profiles/country/ARE.pdf (Accessed: 2.10.2015).

3. (2015) veb-sajt konsaltingovoj kompanii «Russkie Jemiraty»

Available: www.russianemirates.com

(Accessed: 2.10.2015)

4. Egorin AZ, Isaev VA (1997) Ob\#edinennye Arabskie Jemiraty. - Moscow, 1997 - 320 p.

5. Mihin VL (1988) Ob\#edinennye Arabskie Jemiraty. - V kn.: Novejshaja istorija arabskih stran Azii. 1917-1985. Moscow, 1988.
6. Musleh Ajed S.Alahbabi (2007) OAE i vneshnij mir. Moscow: «Nauchnaja kniga», 2007.

7. Musleh Ajed S.Alahbabi (2007) Prioritety i mehanizmy realizacii vneshnej politiki OAJe// Vestnik Rossijskogo universiteta druzhby narodov. Serija «mezhdunarodnye otnoshenija». Moscow, 2007, № 3 (10).

8. Romanova A (2015) Rezervnye fondy RF voshli v top-15 krupnejshih v mire. Available: https://slon.ru/posts/56448 (Accessed: 2.10.2015).

9. Unikal'nye uslovija dlja investorov. //Delovye Jemiraty - 2/3 - 2014. pp.10-14.

10. Jakub Jusef Abdalla (1978) Ob\#edinennye Arabskie Jemiraty. Istorija politikogosudarstvennogo razvitija (19 v. - nachalo 70 gg. 20 v.). - Moscow, 1978. 